\title{
The Correlation of CSR and Consumer Behavior: A Study of Convenience Store
}

\author{
Shwu-Ing $\mathrm{Wu}^{1} \&$ Hsin-Feng $\mathrm{Lin}^{1}$ \\ ${ }^{1}$ Department of Business Administration, National Chin-Yi University of Technology, Taiwan, R.O.C. \\ Correspondence: Shwu-Ing Wu, Professor of Department of Business Administration, National Chin-Yi \\ University of Technology, No.57, Section 2, Chungshan Road, Taiping, Taichung, Taiwan 411, R.O.C. Tel: \\ 886-4-2392-4505. E-mail: wusi@ncut.edu.tw
}

$\begin{array}{ll}\text { Received: September 4, } 2014 & \text { Accepted: October 4, } 2014 \quad \text { Online Published: November 24, } 2014 \\ \text { doi:10.5539/ijms.v6n6p66 } & \text { URL: http://dx.doi.org/10.5539/ijms.v6n6p66 }\end{array}$

\begin{abstract}
In recent years, issues related to corporate social responsibility (CSR) have received more and more attention, it also as the goal of total quality management (TQM). Since CSR can influence enterprise performance. This study explores the impact of the consumer's perception of a company's CSR on brand trust, brand satisfaction, brand attachment, and current and future buying behavior as well as probe into the differences between different generational groups.

A consumer survey produced a total of 753 valid questionnaires which indicate a significant difference in the two correlation paths between the $\mathrm{X}$ and $\mathrm{Y}$ generational groups. This shows that consumers belonging to different generation groups exhibit slightly different correlation patterns as far as the perception of CSR is concerned. Trust in a certain brand on the part of X-generation consumers does not affect their emotional attachment to this brand. Y-generation consumers, on the other hand, are more attached to brands that they trust.
\end{abstract}

\section{Introduction}

th

Corporate Social Responsibility (CSR) has been a widely discussed topic since the 19 century and has turned into a major global issue (Hopkins, 2003). Due to the changing macro environment and technological developments, corporate activities have an even greater impact on the whole social environment, which increases the responsibility of enterprises and leads to a growing importance of CSR (Alsmadi \& Alnawas, 2012). CSR also is the key factor of total quality management (TQM) since it will influence the business performance that is the final goal of TQM, but few researches put attention in this field.

Frederick (1986) points out that if enterprises undertake certain social responsibilities or obligations during the pursuit of commercial activities they can consolidate their relationship with society and thereby enhance their brand image, achieve free advertising, expand their sales volume, and hire high-quality staff. If enterprises are committed to honor their social responsibility, they are also able to improve their operational efficiency and reduce their costs (Sprinkle \& Maines, 2010).

An enhanced corporate image as perceived by consumers is a major factor leading enterprises to conduct CSR-related activities (Yoon, et al., 2006; Giannarakis \& Theotokas, 2011; Mejri \& De Wolf, 2012). Damiano-Teixeira and Pompermayer (2007) proved in their research that consumers do indeed take into account whether or not businesses fulfill their social responsibility and reward or punish enterprises through their actual purchase behavior. Enterprises are therefore willing to shoulder more corporate responsibilities to respond to consumer demands due to their awareness of the connection between consumer behavior and CSR. CSR is therefore the primary factor in the relationship between consumers and the brand, which in turn affects consumer behavior.

The research of Aaker (1996) and Esch et al. (2006) indicates that the fulfillment of CSR has a positive impact on the evaluation of corporate activities by consumers, which in turn has a positive effect on the current purchasing behavior and future purchase intention of consumers. This also signals that consumers who are more aware of CSR are more likely to purchase the products of a certain company, which is the main reason why companies have to implement CSR-related activities (Boonpattarakan, 2012).

Even though enterprises are already aware of the importance of social responsibility and many scholars have 
conducted research on this topic, no research currently exists that covers CSR, brand relationship as well as consumer purchasing behavior. The results of the studies by Blackwell et al. (2006), Gronholdt, Martensen and Kristensen (2000), and Esch et al. (2006) suggest that a positive correlation exists between brand relationship and the current and future purchasing behavior of consumers. In this study, we set the four categories of CSR as proposed by Carroll in 1991 as antecedents for our analysis of the impact of a consumer's perception of CSR on his relationship with the brand and purchase behavior with the goal of making a contribution to the research in this area.

We conducted an analysis on the correlation pattern between CSR on the one hand and brand relationship and consumer behavior on the other. Our independent variables include the four domains of CSR as defined by Carroll: economic responsibility, legal responsibility, ethical responsibility, and philanthrophic responsibility. We selected the three dimensions of brand relationship, namely brand trust, brand satisfaction, and brand attachment, as our intervening variables (Esch et al., 2006). The dependent variables of this study are the current purchasing behavior and future purchase intention of consumers with regard to a certain product or service (Blackwell et al., 2006; Gronholdt, Martensen, \& Kristensen, 2000; Esch et al., 2006).

The 7-ELEVEN stores in Taiwan are our research objects. Due to the fact that these stores which belong to the largest convenience store franchise in Taiwan are spread all over the Taiwan and are well-known among consumers in Taiwan, we will determine in our study whether or not consumers are aware of the franchise's commitment to social responsibilities which will be followed by an analysis of the impact of this perception on the brand relationship and purchasing behavior of consumers as well as a comparison of the different correlation patterns of different generational groups.

\section{Literature review and Discussion}

\subsection{Corporate Social Responsibility}

Carroll and Buchholtz (2011) point out that the term "corporate social responsibility" connotes that enterprise not only have to fulfill their economic and legal obligations but also have other responsibilities that are related to the protection and enhancement of society. In other words, enterprises also should be committed to social welfare and environmental protection to meet the expectations of customers, employees, shareholders, and other involved parties (Sexty, 2010). Carroll (1991) classifies CSR into four dimensions which make up the four layers of a CSR pyramid. This study adopts the four dimensions developed by Carroll, namely economic responsibility, legal responsibility, ethical responsibility, and philanthropic responsibility, and uses them to measure the consumers' perception of CSR.

\subsection{Brand Relationship}

In his discussion of the relationship between the brand and the consumer, Chen (2009) states that this relationship is mainly based on a constant mutual influence in our daily lives and experiences, which in turn leads to common values and concrete meaning. Lee, Jeon and Yoon (2010), on the other hand, believe that consumer affection has a decisive effect on brand attachment.

Morgan and Hunt (1994) emphasize that brand trust and affection connotes the level of a consumer's fondness for the brand. Esch et al. (2006) argue that the three dimensions of brand relationship, namely brand trust, brand satisfaction, and brand attachment, affect the current and future purchases by consumers.

This study adopts the concepts of Esch et al. (2006) as a reference for the measurement of the three brand relationship variables: "brand trust", "brand satisfaction", and "brand attachment".

\subsection{Current Purchasing Behavior}

Blackwell et al. (2006) believe that purchasing behavior refers to the current purchasing activities of consumers regarding a certain product as well as their intention and willingness to purchase that product. Mollen and Wilson (2010) also point out that "current purchasing behavior" mainly refers to the purchase time as well as the purchased amount and the purchased product or service type. This study adopts the concepts of Blackwell et al. (2006) as a reference to measure the current purchasing behavior of consumers. We identified three important variables for the current purchasing behavior of consumers: "Purchase category", "Purchase frequency", and "Purchase amount".

\subsection{Future Purchase Intention}

The application of purchase decision models provides deeper insight in consumer purchase behavior (Wout \& Sanfey, 2008). Only after the consumer perceives the quality and value of a product will he/she form a purchase intention. The purchase intention is often determined by the perceived benefits and values (Kwon \& Schumann, 
2010).

Gronholdt, Martensen and Kristensen (2000) suggest that repurchase intention, price tolerance, cross-buying intentions, and customer recommendations can serve as indicators for the future purchase behavior of customers.

This study adopts the concepts of Gronholdt, Martensen and Kristensen as a reference for the measurement of future purchase intentions of consumers. We also identified the following three variables: "Repurchase intention", "Cross-buying", and "Purchase recommendations"

\section{Research Hypotheses}

\subsection{The Impact of the Consumers' Perception of CSR on Brand Trust}

The fulfillment of social responsibility not only strengthens the consumers' identification with the enterprise but also builds a long-term relationship and value system between the consumer and the enterprise (Alexander, Francis, Kyire, \& Mohammed, 2014; Shamma \& Hassan, 2011; Lee et al., 2011).

Carroll (1991) states that as far as economic responsibility is concerned, enterprises emphasize profit maximization, while consumers demand good quality and fair prices. Enterprises have to make sure they meet both goals. Esch et al. (2006) believe that trust implies that consumers have confidence in the quality of the products or services provided by a certain brand. The relationship of trust built through the fulfillment of economic responsibilities gives enterprises a strong competitive edge.

Fournier (1998) argues that consumers are confident that responsible corporate brands will adhere to the various "rules" composing the implicit relationship contract, deliver what is desired by the consumer, and take full responsibility for their actions, which in turn leads to increased consumer trust.

If consumers have confidence in the reliability of a supplier of products or services, they will also believe that the supplier will meet his responsibilities and obligations as previously agreed (Chaudhuri \& Holbrook, 2001). Consumers will therefore have less doubt about a supplier's moral commitment and will exhibit greater trust.

Langmeyer and Shank (1993) found that recommendations by celebrities tend to be viewed as more professional, reliable and appealing and are also more likely to motivate people to make a donation. Enterprises should therefore not only focus on strengthening their brand image but also on environmental protection, social welfare, and other activities that may enhance their CSR image in order to increase the consumers' trust.

Based on the above discussion, we propose the following hypotheses:

H1a: The consumers' perception of a company's fulfillment of its economic responsibility has positive effect on brand trust.

H1b: The consumers' perception of a company's fulfillment of its legal responsibility has positive effect on brand trust.

H1c: The consumers' perception of a company's fulfillment of its ethical responsibility has positive effect on brand trust.

H1d: The consumers' perception of a company's fulfillment of its philanthropic responsibility has positive effect on brand trust.

\subsection{The Impact of the Consumers' Perception of CSR on Brand Satisfaction}

Esch et al. (2006) believe that satisfaction is a consumer's overall assessment of a product or service purchase experience. An overall positive image of a company in the consumer's eyes leads to higher satisfaction levels and a more positive attitude toward the company on the part of the consumer. A commitment to CSR, on the other hand, is a major factor in the creation of a more positive corporate image (Mohr \& Webb, 2005)

If an enterprise fulfills its social responsibility, a positive effect on the value perception by consumers is generated, which in turn leads to higher consumer satisfaction (Marin et al., 2009). Besides striving for profit maximization and pursuing shareholder interests, enterprises also have to satisfy the demands of consumers, the social environment, and other involved parties (Carvalho, Sen, Oliveira Mota, \& Lima, 2010). In addition, brand identification as a result of the fulfillment of CSR has a direct effect on customer satisfaction levels, which clearly shows that CSR has a direct positive correlation with customer satisfaction levels (Baron \& Kenny, 1986).

Based on the above discussion, we postulate the following hypotheses:

H2a: The consumers' perception of a company's fulfillment of its economic responsibility has positive effect on brand satisfaction. 
H2b: The consumers' perception of a company's fulfillment of its legal responsibility has positive effect on brand satisfaction.

H2c: The consumers' perception of a company's fulfillment of its ethical responsibility has positive effect on brand satisfaction.

H2d: The consumers' perception of a company's fulfillment of its philanthropic responsibility has positive effect on brand satisfaction.

\subsection{The Impact Of Consumer Brand Trust on Brand Attachment}

Esch et al. (2006) argue that brand attachment signifies a certain connection between the consumer and the brand. Consumer purchasing behavior can be stimulated by satisfying the mental needs of consumers. This clearly shows that the strength of brand attachment is determined by the length and process of contact with the brand (Park et al., 2010). If service providers are able to convince their customers that they can offer them what other providers can't, customers have a certain incentive to establish a relationship with the service provider and will be more willing to stay attached to the original provider (Tokman et al., 2007). In addition, Chaudhuri and Holbrook (2001) state that consumers purchase more products from brands that they trust. These brands also cause a high degree of attitudinal attachment on the part of the customer.

Therefore, we propose the following hypothesis.

H3: Consumer brand trust has positive effect on brand attachment.

\subsection{The Impact of Consumer Brand Satisfaction on Brand Attachment and Future Purchase Intention}

Esch et al. (2006) point out that brand satisfaction and brand attachment are the result of exchanges and interactions. After a certain response time, brand satisfaction will affect brand attachment as an end result. For instance, consumers use their preferred brand to establish a connection with the brand or exhibit their own personality through the brand (Fournier, 1998)

Kotler and Keller (2009) discovered that consumers will experience satisfaction or dissatisfaction with a product or service after purchasing it. This mental change affects the future behavior of consumers. Many studies reveal that brand satisfaction is positively correlated with repurchase intention (Huber et al., 2010). The more satisfied customers are with a certain company, the more likely are they to do business with it again or to repurchase the products they offer (Oliver, 1980).

Therefore, we suggest the following hypotheses:

H4: Consumer brand satisfaction has positive effect on brand attachment.

H5: Consumer brand satisfaction has positive effect on future purchase intention.

\subsection{The Impact of Consumer Brand Attachment on Current Purchasing Behavior and Future Purchase Intention}

If a company wants to ensure sustained business operations, it cannot solely rely on brand image and brand reputation. The key to long-term success lies in brand relationship. Positive brand relationships generate brand attachment (Aaker, 1996).

Esch et al. (2006) believe that brand attachment affects the current purchasing behavior and the future purchase intentions. Due to the fact that brand attachment is a relationship that is formed between people and the brand (Park \& MacInnis, 2006); it can predict consumer purchasing behavior (Park et al., 2010).

Kim and Villegas (2009) argue that attachment is a prerequisite for loyalty. If Consumers are attached to a certain brand, it translates into a higher purchase frequency. If consumers are strongly attached to a certain brand, brand loyalty is generated (Park \& Prester, 2007).

Based on the above discussion, we suggest the following hypotheses.

H6: Consumer brand attachment has positive effect on current purchasing behavior.

H7: Consumer brand attachment has positive effect on future purchase intention.

\subsection{The Impact of the Current Purchasing Behavior on Future Purchase Intentions}

Gronholdt, Martensen and Kristensen (2000) believe that the current purchasing behavior of customers can predict whether or not the consumer will purchase the same brand in the future. The concept of purchase intentions has been employed in academic circles to explore the future purchasing behavior of consumers (Morwitz, Steckel, \& Gupta, 2007). Businesses attempt to gain a deeper understanding of current and future consumer demands based on information about product or service purchases by consumers in the hope of gaining the ability to accurately predict the future purchasing behavior (Hanssens et al., 2008). 
Therefore, we postulate the following hypotheses.

H8: The current purchasing behavior of consumers has positive effect on the future purchase intentions.

\subsection{Differences between Different Generational Groups}

Glenn (2005) states that the term generation is refer to people who live in the same age and exhibit similar purchasing behaviors. Due to the fact that they live in the same age, they share their life experiences with each other. They also live in the same cultural and economic environment results in the phenomenon of closely connected generations. This indicates that each generation has the same characteristics and lifestyles. An analysis that is based on generational differences therefore provides deeper insight into the different product, brand, and consumption patterns of each generation (Roberts \& Manolis, 2000). Roberts and Manolis (2000) point out that sales personnel tends to focus on generational consumption behavior since consumers that belong to different generational groups form distinct market segments which can give enterprises a better understanding of current and future market developments and help them provide suitable products and services to satisfy the demands of consumers belonging to different generational groups. As far as the consumers are concerned, they not only expect products and services in an age of diversified consumption but also the fulfillment of corporate social responsibility or, in other words, the provision of added value for society and the environment. We divided our research subjects into two generational groups ( $\mathrm{X}$ and $\mathrm{Y}$ ) to explore whether there are any differences between Gen $\mathrm{X}$ and $\mathrm{Y}$ consumers as far as the correlation patters and paths for the perception of CSR are concerned. Therefore, we propose the following hypotheses:

H9: Consumer groups belonging to different generational groups show a significant difference in the correlation patterns.

\section{Research Design}

\subsection{Research Framework}

The four dimensions proposed by Carroll in 1991 (economic responsibility, legal responsibility, ethical responsibility, and philanthropic responsibility) served as the independent variables of this study. We explored whether or not these independent variables affect the intervening variables (brand trust, brand satisfaction, and brand attachment) and the dependent variables (current purchasing behavior and future purchasing intentions) with the final goal of conducting a comparative analysis of the differences between the $\mathrm{X}$ and $\mathrm{Y}$ generations. Our research framework is shown in Figure 1.

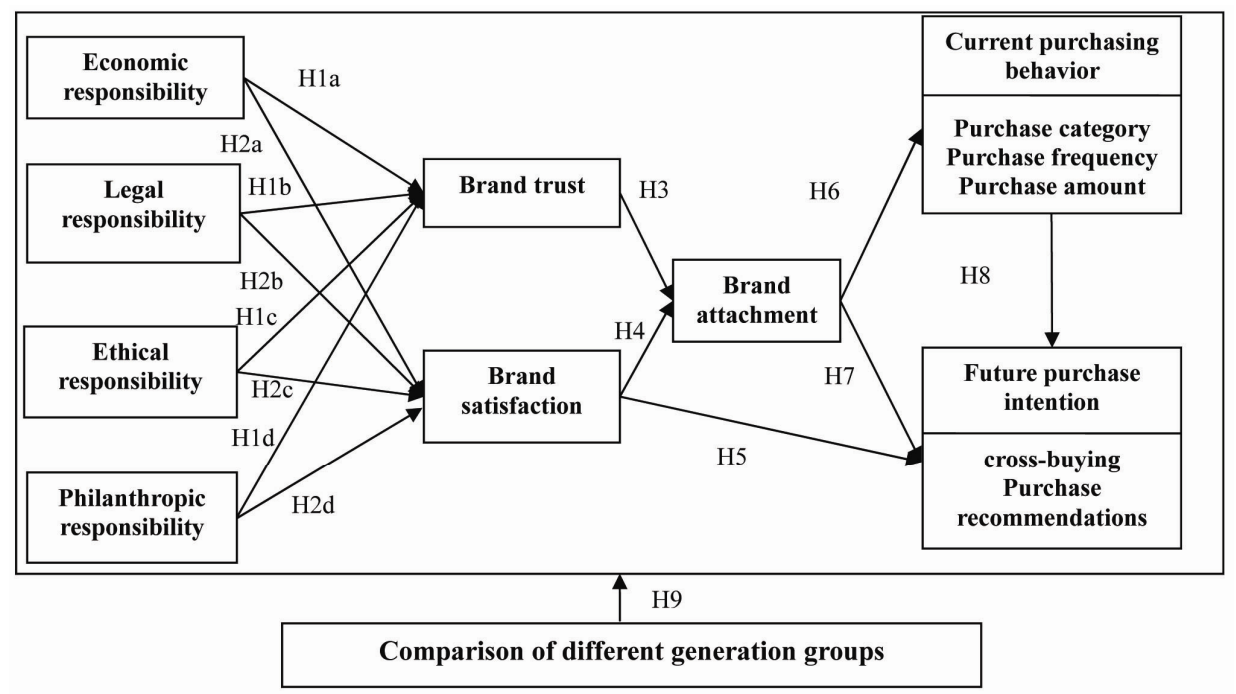

Figure 1. Research framework

\subsection{Questionnaire Design}

In order to obtain an effective measuring tool, we conducted a Pretest and Pilot study before handing out the official questionnaire to make necessary revisions. For the pretest, we conducted in-depth interviews of 30 consumers who have made purchases at 7-Eleven Convenience Stores in Taiwan and who have been selected 
through convenience sampling. We discovered that some of the questions were worded unclearly; we therefore revised the wording and added examples for clarification. After the necessary adjustments had been made, we selected 100 respondents through convenience sampling for our Pilot study and conducted a reliability and validity analysis for their responses.

The results of the Pilot study indicated that Cronach's alpha scores ranged between 0.771 and 0.942 , and were all above the standard of 0.7 and the Item-to-Total Correlation Coefficients were greater than or close to 0.5 which signals a high reliability of all dimensions (Nunnally, 1978; Kerlinger, 1978). The results of the factor analysis also showed that the eigenvalues of all dimensions were higher than 1 and the cumulative explained variation was greater than or close to 0.5 , the factor loading of all variables was greater than or close to 0.5 which indicates that all dimensions possess convergent validity (Kaiser, 1958). We therefore conducted our official survey with this questionnaire. We adopted a 7-point Likert scale for our questionnaire with the following point values: $1=$ strongly disagree to $7=$ strongly agree. In addition, the demographic data was measured with a nominal scale.

\section{Research Results}

\subsection{Sampling}

We conducted an empirical sample survey by handing out questionnaires over a period of three months. The research subjects of this study were Taiwanese consumers of 15 years or above with the population distribution statistics for Taiwan published by the Directorate-General of Budget, Accounting, and Statistics of the Executive Yuan as a reference basis. The population percentages for the four major areas (North, Center, South, and East) are $45 \%, 25 \%, 28 \%$, and $3 \%$, respectively. 800 questionnaires were distributed by using the quota sampling method. 47 invalid questionnaires had to be eliminated, which left a total of 753 valid questionnaires representing a valid response rate of $94 \%$. As for the geographical areas, $345(45.8 \%)$ respondents were from Northern Taiwan, while 189 (25.1\%), 204 (27.1\%), and 15(2\%) hailed from Central, Southern and Eastern Taiwan, respectively. Demographic breakdown as Table 1.

Table 1. Demographic of sample

\begin{tabular}{|c|c|c|c|}
\hline Items & Category & Number & $\%$ \\
\hline \multirow{4}{*}{ Living area } & 1. North & 345 & $45.8 \%$ \\
\hline & 2. Center & 189 & $25.1 \%$ \\
\hline & 3. South & 204 & $27.1 \%$ \\
\hline & 4. East & 15 & $2.0 \%$ \\
\hline \multirow{5}{*}{ Education } & 1. Junior & 32 & $4.2 \%$ \\
\hline & 2. High School & 244 & $32.4 \%$ \\
\hline & 3. University & 395 & $52.5 \%$ \\
\hline & 4. Mater & 70 & $9.3 \%$ \\
\hline & 5. Doctor & 12 & $1.6 \%$ \\
\hline \multirow{8}{*}{ Career } & 1. Services industry & 154 & $20.5 \%$ \\
\hline & 2. Government officials & 66 & $8.8 \%$ \\
\hline & 3. Financial Industry & 79 & $10.5 \%$ \\
\hline & 4. Self Employed & 60 & $8.0 \%$ \\
\hline & 5. IT industry & 49 & $6.5 \%$ \\
\hline & 6. House wife & 18 & $2.4 \%$ \\
\hline & 7. Student & 252 & $33.5 \%$ \\
\hline & 8. Others & 75 & $10.0 \%$ \\
\hline \multirow{6}{*}{ Income/per month } & 1. NT $\$ 10,000$ or less & 241 & $32.0 \%$ \\
\hline & 2. NT\$10,001 30,000 & 262 & $34.8 \%$ \\
\hline & 3. NT $\$ 30,001 \sim 50,000$ & 135 & $17.9 \%$ \\
\hline & 4. NT\$50,001 70,000 & 74 & $9.8 \%$ \\
\hline & 5. NT\$70,001 90,000 & 11 & $1.5 \%$ \\
\hline & 6. NT $\$ 90,000$ or above & 30 & $4.0 \%$ \\
\hline
\end{tabular}

\subsection{Reliability and Validity Analysis of the Official Questionnaire}

The reliability and validity of the official questionnaire was evaluated with the Cronbach's $\alpha$ and a factor analysis. Based on Nunnally (1978)'s rule of thumb of 0.7 or greater as an indicator for high reliability for Cronbach's alpha coefficients and Kerlinger (1978)'s judgment criterion for Item to Total Correlation 
Coefficients which requires values of 0.5 or greater, it is evident that the overall reliability of the questionnaire is therefore very good as shown in Table 2.

Based on the evaluation criteria for convergent validity, all standardized factor loadings have to be greater than 0.5 (Hair et al., 2006), composite reliability (CR) has to be greater than 0.6 (Fornell\& Larcker, 1981), and average variance extracted (AVE) has to be greater than 0.5 (Bagozzi \& Yi, 1988). Kaiser (1958), on the other hand, states that the eigenvalues of the extracted factors have to exceed 1 and the cumulative explained variation has to be greater than 0.5. It was evident that the values for all dimensions exceeded or were close to these standards. The convergent validity of our questionnaire is therefore very good as shown in Table 2.

According to the suggestions by Fornell \& Larcker (1981), the square roots of the AVEs should be greater than the correlation coefficients of the dimensions. Our results show that these requirements are met, which in turn indicates that the questionnaire possesses good discriminant validity (shown in Table 3).

Table 2. Reliability and validity analysis of the questionnaire $(\mathrm{n}=753)$

\begin{tabular}{|c|c|c|c|c|c|c|c|c|}
\hline $\begin{array}{l}\text { Research } \\
\text { dimensions }\end{array}$ & Measurement variables & $\begin{array}{l}\text { Item-to-total } \\
\text { correlation } \\
\text { coefficients }\end{array}$ & Cronbach $\alpha$ & $\begin{array}{l}\text { Factor } \\
\text { loading }\end{array}$ & $\begin{array}{l}\text { Eigen- } \\
\text { value }\end{array}$ & $\begin{array}{l}\text { Cumulative } \\
\text { explained } \\
\text { variation \% } \\
\end{array}$ & $\mathrm{CR}$ & AVE \\
\hline \multirow[t]{6}{*}{ Economic CSR } & $\begin{array}{l}\text { I think that 7-Eleven can stimulate } \\
\text { economic activities in Taiwan }\end{array}$ & 0.626 & 0.836 & 0.781 & 3.310 & 55.164 & 0.880 & 0.552 \\
\hline & $\begin{array}{l}\text { I think that } 7 \text {-Eleven provides advantages } \\
\text { for consumers }\end{array}$ & 0.677 & & 0.801 & & & & \\
\hline & $\begin{array}{l}\text { I think that } 7 \text {-Eleven has a higher } \\
\text { operational efficiency }\end{array}$ & 0.533 & & 0.705 & & & & \\
\hline & $\begin{array}{l}\text { I think that } 7 \text {-Eleven provides great value } \\
\text { products }\end{array}$ & 0.621 & & 0.717 & & & & \\
\hline & $\begin{array}{l}\text { I think that } 7 \text {-Eleven offers reasonably } \\
\text { priced products }\end{array}$ & 0.573 & & 0.679 & & & & \\
\hline & $\begin{array}{l}\text { I think that } 7 \text {-Eleven can stimulate the } \\
\text { local markets }\end{array}$ & 0.619 & & 0.765 & & & & \\
\hline \multirow[t]{5}{*}{ Legal CSR } & $\begin{array}{l}\text { I think that 7-Eleven abides by legal } \\
\text { regulations }\end{array}$ & 0.757 & 0.911 & 0.847 & 3.695 & 73.899 & 0.934 & 0.739 \\
\hline & $\begin{array}{l}\text { I think that } 7 \text {-Eleven abides by all } \\
\text { transaction laws and regulations }\end{array}$ & 0.832 & & 0.899 & & & & \\
\hline & $\begin{array}{l}\text { I think that 7-Eleven meets all required } \\
\text { regulations }\end{array}$ & 0.788 & & 0.870 & & & & \\
\hline & $\begin{array}{l}\text { I think that } 7 \text {-Eleven meets all its legal } \\
\text { obligations }\end{array}$ & 0.795 & & 0.874 & & & & \\
\hline & $\begin{array}{l}\text { I think that the products and services } \\
\text { provided by } 7 \text {-Eleven comply with the } \\
\text { regulations of our country }\end{array}$ & 0.703 & & 0.805 & & & & \\
\hline \multirow[t]{5}{*}{ Ethical CSR } & $\begin{array}{l}\text { I think that 7-Eleven meets the } \\
\text { expectations of society }\end{array}$ & 0.737 & 0.880 & 0.847 & 3.392 & 67.835 & 0.913 & 0.678 \\
\hline & $\begin{array}{l}\text { I think that } 7 \text {-Eleven respects the moral } \\
\text { standards of our society }\end{array}$ & 0.763 & & 0.864 & & & & \\
\hline & $\begin{array}{l}\text { I think that } 7 \text {-Eleven will handle defective } \\
\text { products to the satisfaction of consumers }\end{array}$ & 0.582 & & 0.712 & & & & \\
\hline & $\begin{array}{l}\text { I think that } 7 \text {-Eleven is trustworthy and } \\
\text { reliable }\end{array}$ & 0.736 & & 0.840 & & & & \\
\hline & $\begin{array}{l}\text { I think that } 7 \text {-Eleven abides by its } \\
\text { commercial ethical standards }\end{array}$ & 0.740 & & 0.846 & & & & \\
\hline \multirow[t]{4}{*}{$\begin{array}{l}\text { Philanthropic } \\
\text { CSR }\end{array}$} & $\begin{array}{l}\text { I think that 7-Eleven meets the } \\
\text { expectations of society in the field of } \\
\text { philanthropic activities }\end{array}$ & 0.804 & 0.919 & 0.891 & 3.218 & 80.456 & 0.943 & 0.804 \\
\hline & $\begin{array}{l}\text { I think that 7-Eleven organizes or sponsors } \\
\text { philanthropic activities }\end{array}$ & 0.840 & & 0.914 & & & & \\
\hline & $\begin{array}{l}\text { I think that the 7-Eleven staff participates } \\
\text { in philanthropic activities on a voluntary } \\
\text { basis }\end{array}$ & 0.781 & & 0.876 & & & & \\
\hline & $\begin{array}{l}\text { I think that } 7 \text {-Eleven participates in public } \\
\text { welfare activities }\end{array}$ & 0.827 & & 0.906 & & & & \\
\hline
\end{tabular}




\begin{tabular}{|c|c|c|c|c|c|c|c|c|}
\hline \multirow{4}{*}{ Brand trust } & I think that 7-Eleven deserves to be trusted & 0.764 & 0.862 & 0.877 & 3.250 & 65.006 & 0.902 & 0.650 \\
\hline & $\begin{array}{l}\text { I have trust in the } 7 \text {-Eleven service and } \\
\text { product quality }\end{array}$ & 0.761 & & 0.872 & & & & \\
\hline & $\begin{array}{l}\text { I think that 7-Eleven gives first priority to } \\
\text { consumer benefits }\end{array}$ & 0.516 & & 0.663 & & & & \\
\hline & $\begin{array}{l}\text { I think that } 7 \text {-Eleven has a high brand } \\
\text { reputation }\end{array}$ & 0.577 & & 0.734 & & & & \\
\hline \multirow[t]{4}{*}{$\begin{array}{l}\text { Brand } \\
\text { satisfaction }\end{array}$} & $\begin{array}{l}\text { I think that the } 7 \text {-Eleven sales process is } \\
\text { highly efficient }\end{array}$ & 0.697 & 0.868 & 0.811 & 3.281 & 65.619 & 0.905 & 0.656 \\
\hline & $\begin{array}{l}\text { I think that the 7-Eleven service personnel } \\
\text { has a very positive attitude }\end{array}$ & 0.598 & & 0.732 & & & & \\
\hline & $\begin{array}{l}\text { I think that } 7 \text {-Eleven products and services } \\
\text { are reliable }\end{array}$ & 0.729 & & 0.837 & & & & \\
\hline & $\begin{array}{l}\text { I think that the services and products } \\
\text { provided by } 7 \text {-Eleven are highly satisfying } \\
\text { to consumers }\end{array}$ & 0.724 & & 0.838 & & & & \\
\hline \multirow{4}{*}{$\begin{array}{l}\text { Brand } \\
\text { attachment }\end{array}$} & I strongly identify with 7-Eleven & 0.748 & 0.893 & 0.860 & 3.030 & 75.751 & 0.926 & 0.757 \\
\hline & $\begin{array}{l}\text { I think that 7-Eleven can provide me with } \\
\text { a greater level of satisfaction than other } \\
\text { convenience stores }\end{array}$ & 0.783 & & 0.884 & & & & \\
\hline & $\begin{array}{l}\text { I think that 7-Eleven products can be used } \\
\text { safely and without risk }\end{array}$ & 0.796 & & 0.892 & & & & \\
\hline & $\begin{array}{l}\text { I think that the shopping experience at } \\
\text { 7-Eleven is an important part of my daily } \\
\text { life }\end{array}$ & 0.725 & & 0.844 & & & & \\
\hline \multirow{7}{*}{$\begin{array}{l}\text { Current } \\
\text { purchasing } \\
\text { behavior }\end{array}$} & $\begin{array}{l}\text { I use different services provided by } \\
\text { 7-Eleven }\end{array}$ & 0.582 & & 0.673 & & & & \\
\hline & $\begin{array}{l}\text { I'm highly familiar with the 7-ELEVEn } \\
\text { product categories and items }\end{array}$ & 0.744 & & 0.814 & & & & \\
\hline & $\begin{array}{l}\text { I purchase products and services at } \\
\text { 7-Eleven on a daily basis }\end{array}$ & 0.777 & & 0.839 & & & & \\
\hline & $\begin{array}{l}\text { I purchase products and services at } \\
\text { 7-Eleven more often than other people }\end{array}$ & 0.768 & & 0.829 & & & & \\
\hline & $\begin{array}{l}\text { I think that 7-Eleven promotional } \\
\text { activities stimulate my purchasing desire }\end{array}$ & 0.704 & & 0.777 & & & & \\
\hline & $\begin{array}{l}\text { I think that shopping at } 7 \text {-Eleven makes up } \\
\text { a large part of my daily shopping activities }\end{array}$ & 0.771 & & 0.831 & & & & \\
\hline & $\begin{array}{l}\text { I think that 7-Eleven's own brands are } \\
\text { superior to other brands }\end{array}$ & 0.679 & & 0.754 & & & & \\
\hline \multirow[t]{6}{*}{$\begin{array}{l}\text { Future purchase } \\
\text { intention }\end{array}$} & $\begin{array}{l}\text { I intend to continue to purchase 7-Eleven } \\
\text { products and services }\end{array}$ & 0.790 & 0.924 & 0.856 & 4.813 & 68.762 & 0.939 & 0.688 \\
\hline & $\begin{array}{l}\text { I would gladly repurchase 7-Eleven } \\
\text { products or services }\end{array}$ & 0.776 & & 0.845 & & & & \\
\hline & $\begin{array}{l}\text { I prefer 7-Eleven products and services to } \\
\text { those of other convenience stores }\end{array}$ & 0.713 & & 0.794 & & & & \\
\hline & $\begin{array}{l}\text { I am willing to participate in 7-Eleven } \\
\text { promotional activities }\end{array}$ & 0.766 & & 0.835 & & & & \\
\hline & $\begin{array}{l}\text { I'm willing to accept the recommendations } \\
\text { of 7-Eleven service personnel about } \\
\text { different products or services }\end{array}$ & 0.772 & & 0.837 & & & & \\
\hline & $\begin{array}{l}\text { I would recommend my friends or } \\
\text { relatives to purchase } 7 \text {-Eleven products or } \\
\text { services }\end{array}$ & 0.770 & & 0.831 & & & & \\
\hline
\end{tabular}


Table 3. Discriminant validity analysis

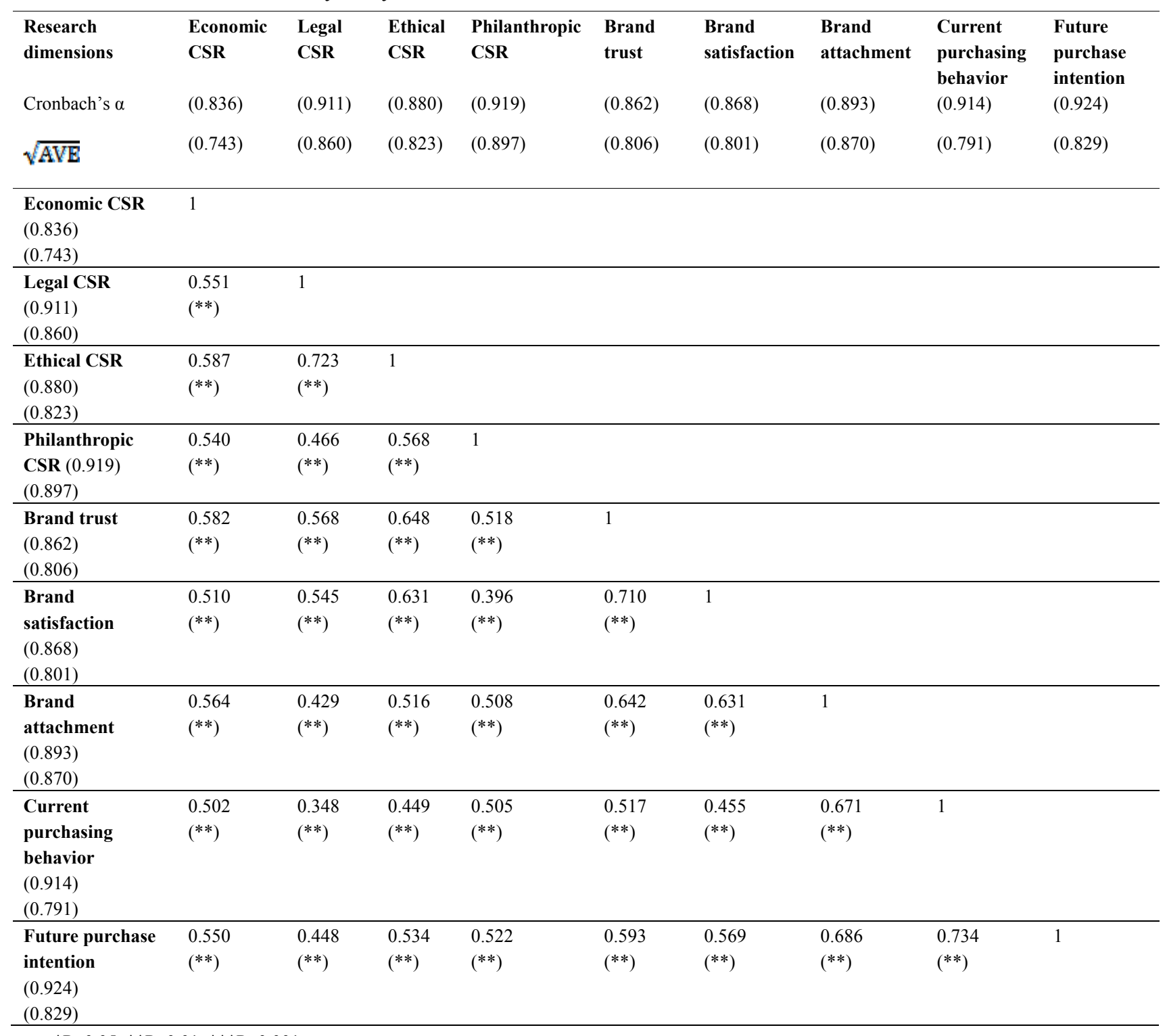

*P $<0.05,{ }^{*} \mathrm{P}<0.01,{ }^{* * *} \mathrm{P}<0.001$.

\subsection{Competing Model Analysis}

We relied on the concepts about the X and Y generational groups proposed by Jim Surmanek in 2005 for our categorization of the 753 valid questionnaires. The respondents were categorized according to their age and we conducted a comparative analysis for these two generations (due to the small sample size, we didn't conduct an analysis for the age group above 50). Consumers between 31 and 50 years of age are regarded as members of the X generation. A total of 267 respondents belonged to this age group with a birth year between 1965 and 1979 . Consumers below 30 years of age were classified as belonging to the $Y$ generation. A total of 440 respondents belonged to this group. All members of the Y generation were born after 1980 and are children of the baby boomer generation (Kong-Fa Cheng, 2011).

We employed an AMOS software program to conduct a competition model analysis of the two groups to explore whether or not generational groups have a significant impact on the correlation between the dimensions. The goodness-of-fit of the competition model is $\chi 2 / \mathrm{df}=2.155$, $\mathrm{RMR}=0.145$, GFI $=0780$, AGFI $=0.751$, NFI $=0843$, $\mathrm{RFI}=0.829, \mathrm{CFI}=0.908, \mathrm{RMSEA}=0.040$ (as shown in Table 4 ). This clearly shows that the fit indicators meet the following requirements: GFI, AGFI, and NFI values greater than 0.8 (Forza \& Filippini, 1998), a CFI value greater than 0.9 (Hair et al., 2006). An RMSEA value smaller than 0.05 (Brown \& Cudeck, 1993), and 2 / $\mathrm{df} \leqq 3$ (Chau \& Hu, 2001). This in turn signals that this model is acceptable. The competing model analysis 
produced the following results:

(1). Our analysis of the correlations between the dimensions for the $\mathrm{X}$ generation shows that all hypotheses (H1a, $\mathrm{H} 1 \mathrm{c}, \mathrm{H} 2 \mathrm{a}, \mathrm{H} 2 \mathrm{c}, \mathrm{H} 4, \mathrm{H} 5, \mathrm{H} 6, \mathrm{H} 8$ ) besides H1b, H1d, H2b, H2d, H3 and H7 are confirmed by our data. Among all paths, moral responsibility and brand satisfaction exhibited the strongest correlation, which was followed by brand attachment and current purchasing behavior, and then moral responsibility and brand trust as shown in Table 4.

(2). The results of Y-Generation analysis of the correlations between the dimensions show that all hypotheses (H1a, H1c, H2a, H2c, H3, H4, H5, H6, H7, H8) except (H1b, H1d, H2b, H2d) are confirmed by our data. The paths exhibiting the strongest impact path is from brand attachment to current purchasing behavior, followed by moral responsibility to brand satisfaction and, finally, brand satisfaction to brand attachment as shown in Table 4.

(3). The results of the T-Test which are shown in Table 3 clearly indicate that that there is a significant difference in the strength of the correlation between brand attachment and the current purchasing behavior of consumers for the $\mathrm{X}$ and $\mathrm{Y}$ generational groups $\left(\mathrm{t}=3.934^{* * *}\right)$. The consumer group that belongs to the $\mathrm{Y}$ generation exhibits a stronger correlation for this path $(0.685>0.672)$. There is also a significant difference in the strength of the correlation between brand attachment and future purchase intentions of consumers for the X-and Y-generations $\left(\mathrm{t}=-2.419^{*}\right)$. The consumer group that belongs to the $\mathrm{Y}$ generation exhibits a stronger correlation for this path $(0.358>0.089)$. These results clearly show that the $\mathrm{Y}$ generation has a greater impact on these correlation patterns ( $\mathrm{H6}$ and $\mathrm{H} 7$ ) than the $\mathrm{X}$ generation. This signals that the brand attachment of the $\mathrm{Y}$ Generation has a stronger impact on current and future purchasing behavior than that of the X Generation. H9 is therefore partly supported by our results.

Table 4. Competing model analysis of different generation groups

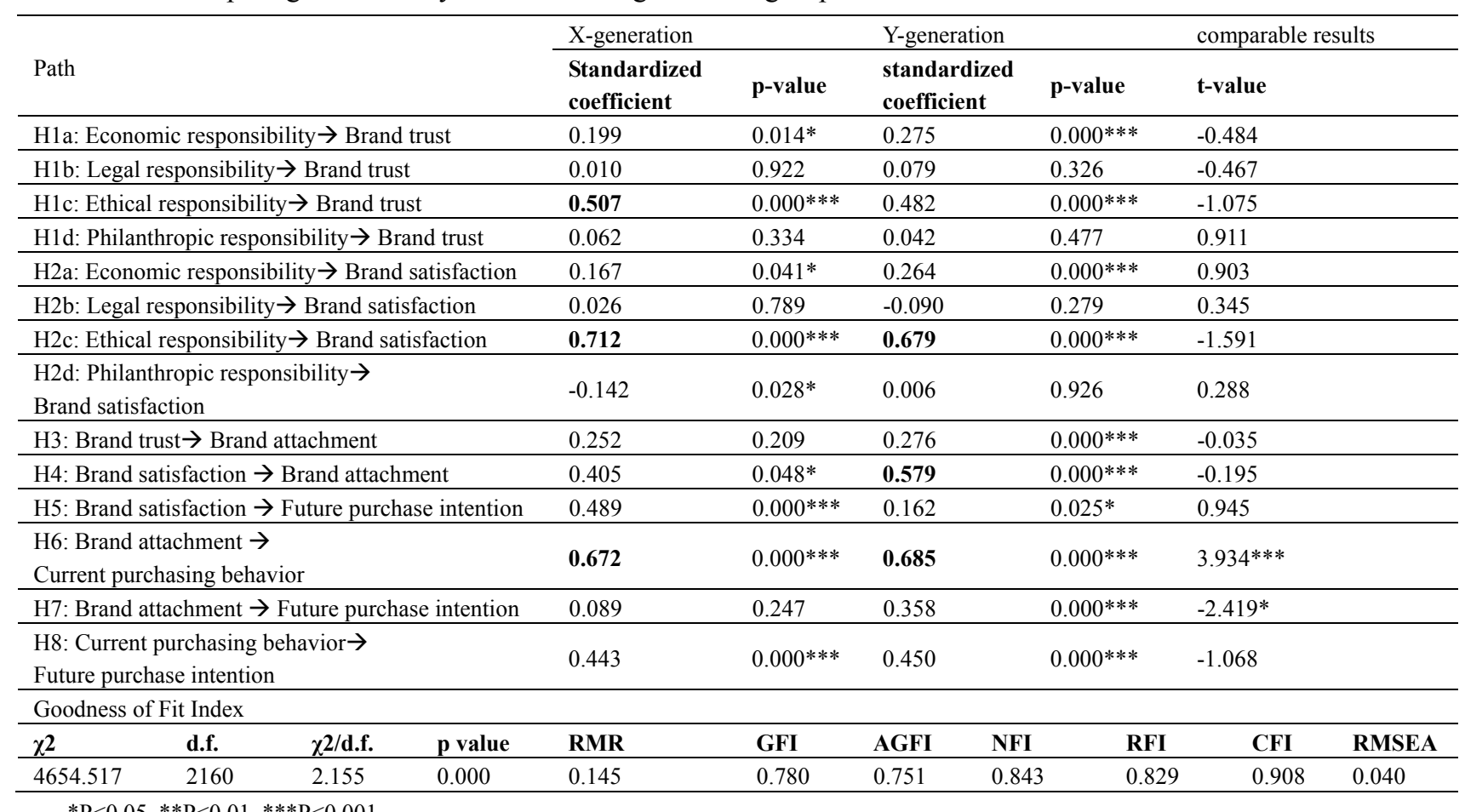

$* \mathrm{P}<0.05, * * \mathrm{P}<0.01, * * * \mathrm{P}<0.001$

\section{Conclusion and Suggestions}

\subsection{Research Conclusions}

The results of the path analysis for different generations indicate that the correlation patterns for the two generations are slightly different:

(1). The correlation paths for the $\mathrm{X}$ - and $\mathrm{Y}$-Generation consumer groups are as follows: 
a. The X-and Y-Generation consumer groups both exhibit significant positive correlations between fulfillment of economic responsibility and consumer brand trust. This result also verifies the theses advanced by Esch et al. (2006) which in turn signals that enterprises that meet their economic responsibility provide society with reasonably priced products and services and engender consumer trust to fulfill their basic responsibility.

b. The X-and Y-Generation consumer groups both exhibit significant positive correlations between fulfillment of ethical responsibility and consumer brand trust. This result also verifies the theses advanced by Chaudhuri and Holbrook (2001). This indicates that corporate behavior that is based on moral obligations convinces consumers that the enterprise deserves to be trusted.

c. The X-and Y-Generation consumer groups both exhibit significant positive correlations between fulfillment of economic responsibility and consumer brand satisfaction. This result also verifies the theses advanced by Marin et al. (2009). This signals that enterprises that meet their economic responsibility provide society with reasonably priced products and services and engender consumer satisfaction as well as affect consumer intentions.

d. The X-and Y-Generation consumer groups both exhibit significant positive correlations between fulfillment of ethical responsibility and consumer brand satisfaction. This result also verifies the theses advanced by Maignan et al., (2005). This indicates that corporate behavior that is based on moral obligations increases consumer satisfaction levels with that enterprise.

e. The X-and Y-Generation consumer groups both exhibit significant positive correlations between consumer brand satisfaction and brand attachment. This result also verifies the theses advanced by Blackston (2000). This signals that enterprises engender consumer satisfaction through their products and services, which in turn increases the willingness of consumers to attach themselves to the brand.

f. The X-and Y-Generation consumer groups both exhibit significant positive correlations between consumer brand satisfaction and future purchase intention. This result also verifies the theses advanced by Huber, Vollhardt, Matthes and Vogel (2010). This indicates that if consumers purchase products or acquire services, they will experience satisfaction with the brand, which in turn affects future purchase intentions by consumers.

g. The X-and Y-Generation consumer groups both exhibit significant positive correlations between consumer brand attachment and current purchasing behavior. This result also verifies the theses advanced by Park and Prester (2007); Park et al. (2010). This signals that consumer brand attachment generates a higher purchase frequency, which in turn leads to higher brand loyalty.

h. The X-and Y-Generation consumer groups both exhibit significant positive correlations between current purchasing behavior and future purchase intentions. This result also verifies the theses advanced by Hanssens et al.(2008). This indicates that the amount of currently purchased products and services positively affects the willingness of consumers to make purchases in the future.

(2). Differences between the X-and Y-Generation consumer groups

a. The $\mathrm{X}$ generation exhibits a significant positive correlation between the fulfillment of philanthropic responsibility by enterprises and consumer brand satisfaction, while the $\mathrm{Y}$ generation does not exhibit a significant correlation pattern for this path. This indicates that Y-Generation consumers tend to fail to make a connection between philanthropic behavior and brand satisfaction, which in turn explains the lack of a positive effect on the brand.

b. The X generation doesn't exhibit a significant correlation between brand trust and brand attachment, while the Y generation displays a significant positive correlation between the two variables. This result also verifies the theses advanced by Tokman et al. (2007). This also indicates that if Y-Generation consumers develop trust in a brand, they will be more willing to attach themselves to this brand.

c. The X generation doesn't exhibit a significant correlation between brand attachment and future purchase intention, while the $\mathrm{Y}$ generation consumers display a significant positive correlation between these variables. This result also verifies the theses advanced by Kim and Villegas (2009). This also signals that brand attachment on the part of Y-Generation consumers has a positive effect on future purchase intentions of consumers.

d. The $\mathrm{Y}$ generation exhibits a stronger correlation than the $\mathrm{X}$ generation for the following paths: brand attachment and current purchasing behavior as well as brand attachment and future purchase intentions. This indicates that brand attachment on the part of Y-Generation consumers generates a higher purchase frequency and increased future purchase intentions on the part of these consumers.

\subsection{Management Implications}

Besides determining the correlation patterns between the different dimensions, we established research tools and 
related concepts that allow an effective measurement of our variables and possess high practical value for the business world.

The results of this study indicate that consumers belonging to different generational groups are influenced by the fulfillment of CSR in different ways. While brand trust on the part of X-Generation consumers has no effect on brand attachment, it does have a positive impact on the brand attachment of Y-Generation consumers. This in turn indicates that younger consumers place greater emphasis on brand trust and are more attached to brands they trust. If Y-Generation consumers are more attached to a certain brand, it will increase their purchase intentions. As far as Y-Generation consumers are concerned, enterprises should therefore focus on the implementation of economic and ethical responsibilities to strengthen brand trust in order to increase purchase intentions through brand attachment. If X-Generation consumers are attached to a certain brand, it does not necessarily lead to increased purchase intentions. The perception of ethical responsibility on the part of $\mathrm{X}$ generational groups, however, increases their satisfaction levels and purchase intentions. As far as X-Generation consumers are concerned, enterprises should therefore focus on strengthening their moral image and provide these consumers with a better understanding of their efforts in the field of ethical responsibilities to generate purchase behavior.

We therefore recommend that enterprises should employ different marketing strategies that are tailored to different generational groups so that consumers can identify with their positive image in the field of CSR, which in turn generates purchase behavior. In addition, businesses should gain a deeper understanding of the main factors determining the impact of CSR on different generational groups, which in turn is beneficial for the planning of CSR-related activities and the formulation of marketing strategies. For instance, the promotion of the benefits and importance of CSR increases the awareness of consumers about CSR, which in turn has a positive impact on current purchasing behavior and future purchase intentions.

\subsection{Research Limitations and Recommendations for Future Research}

We solely focused on 7-Eleven customers and did not consider other store types. Our results might therefore not be applicable to other business sectors. Follow-up studies should therefore include other business sectors as research targets to achieve a higher degree of generalization of the research results.

\section{References}

Aaker, D. A. (1996). Measuring brand equity across products and markets. California Management Review, 38(3), 102-120. http://dx.doi.org/10.2307/41165845

Alexander, A., Francis, A., Kyire, L. A., \& Mohammed, H. (2014). The effect of corporate social responsibility on brand building. International Journal of Marketing Studies, 6(3), 126-134. http://dx.doi.org/10.5539/ijms.v6n3p126

Alsmadi, S., \& Alnawas, I. (2012). Consumer rights today: Are they in business or out of business? International Journal of Marketing Studies, 4(1), 159-167. http://dx.doi.org/10.5539/ijms.v4n1p159

Bagozzi, R. P., \& Yi, Y. (1988). On the Evaluation for Structural Equation Models. Journal of the Academy of Marketing Science, 16(1), 74-94. http://dx.doi.org/10.1007/BF02723327

Baron, R. M., \& Kenny, D. A. (1986). The Moderator Mediator Variable Distinction in Social Psychological Research: Conceptual, Strategic, and Statistical Consideration. Journal of Personality and Social Psychology, 51, 1173-1182. http://dx.doi.org/10.1037/0022-3514.51.6.1173

Blackwell, R., Miniard, P., \& Engel, J. (2006). Consumer behavior. Mason, Ohio: Thomson/South-Western.

Boonpattarakan, A. (2012). An experimental design to test the main and interaction effects of CSR involvement, brand naming and pricing on purchase intentions in Thailand. International Journal of Business and Management, 7(16), 62-79. http://dx.doi.org/10.5539/ijbm.v7n16p62

Bowen, H. R. (1953). Social responsibility of the businessman. New York: Harper \& Row.

Browne, M. W., \& Cudeck, R. (1993). Alternative ways of assessing modelfit. In K. A. Bollen \& J. S. Long (Eds.), Testing structural equationmodels (pp. 136-162). Newbury Park, CA: Sage.

Carmines, E., \& McIver, J. (1981). Analyzing Models with unobserved variables: analysis of covariance structures. In G. Bohmstedt \& E. Borgatta (Eds.), Social measurement: Current Issues. Beverly Hills, Calif: Sage.

Carroll, A. B. (1991). The pyramid of corporate social responsibility: Toward themoral management of $\begin{array}{llll}\text { organizational } \quad \text { stakeholders. } & \text { Business } & \text { Horizons, } & 34(4),\end{array}$ http://dx.doi.org/10.1016/0007-6813(91)90005-G 
Carroll, A. B., \& Buchholtz, A. K. (2011). Business and Society: Ethics, Sustainability, and Stakeholder Management (8th ed.). Mason, OH: South-Western.

Carvalho, S., Sen, S., Oliveira Mota, M., \& Lima, R. (2010). Consumer Reactions to CSR: A Brazilian Perspective. Journal of Business Ethics, 91, 291-310. http://dx.doi.org/10.1007/s10551-010-0620-0

Chau, P. Y. K., \& Hu, P. J. H. (2001). Information Technology Acceptance by Individual Professionals: A Model $\begin{array}{lllll}\text { Comparison Approach. } & \text { Decision } & \text { Sciences, } & 32(4), & \text { 699-719. }\end{array}$ http://dx.doi.org/10.1111/j.1540-5915.2001.tb00978.x

Chaudhuri, A., \& Holbrook, M. B. (2001). The Chain of Effects from Brand Trust and Brand Affect to Brand Performance: The Role of Brand Loyalty. Journal of Marketing, 65(2), 81-93. http://dx.doi.org/10.1509/jmkg.65.2.81.18255

Chen, L. C. P. (2009). Exploring brand relationship developments in e-government. Paper presented at the 2009 International Conference on e-Commerce, e-Administration, e-Society, and e-Education, Singapore.

Cheng, K. F. (2011). Consumer Behavior-Life and Marketing. Taipei: Future Career Publishing Corporation.

Damiano-Teixeira, K. M., \& Pompermayer, M. M. (2007). Corporate Social Responsibility: Profile and Diagnosis of 797 Programs Developed in Brazil. Business and Society Review, 112(3), 343-367. http://dx.doi.org/10.1111/j.1467-8594.2007.00300.x

Esch, F., Langner, T. B., Schmitt, H., \& Geus, P. (2006). Are brands forever? How brand knowledge and relationships affect current and future purchases. The Journal of Product and Brand Management, 15(2), 98-105. http://dx.doi.org/10.1108/10610420610658938

Fornell, C., \& Larcker, D. F. (1981). Evaluating Structural Equation Models with Unobservable Variables and Measurement Error. Journal of Marketing Research, 18(February), 39-50. http://dx.doi.org/10.2307/3151312

Forza, C., \& Filippini, R. (1998). TQM impact on quality conformance and customer satisfaction: a causal model. $\begin{array}{llll}\text { International Journal of Production } & \text { Economics, } & 55(1), & 1-20 .\end{array}$ http://dx.doi.org/10.1016/S0925-5273(98)00007-3

Fournier, S. (1998). Consumers and their brands: developing relationship theory in consumer research. Journal of Consumer Research, 24(4), 343-373. http://dx.doi.org/10.1086/209515

Frederick, W. (1986). Corporate Citizenship: Some Typologies. Bloomington, IN: Indiana University Press.

Gaski, J. F., \& Nevin, J. R. (1985). The differential effects of exercised and unexercised power sources in a marketing channel. Journal of Marketing Research, 22(2), 130-142. http://dx.doi.org/10.2307/3151359

Giannarakis, G., \& Theotokas, I. (2011). The effect of financial crisis in corporate social responsibility performance.International Journal of Marketing Studies, 3(1), 2-10. http://dx.doi.org/10.5539/ijms.v3n1p2

Glenn, N. D. (2005). Cohort Analysis (2th ed.). California: SAGE.

Gronholdt, L., Martensen, A., \& Kristensen, K. (2000). The Relationship between Customer Satisfaction and Loyalty: Cross-Industry Differences. Total Quality Management, 11(5), 509-516. http://dx.doi.org/10.1080/09544120050007823

Hair, J. F., Black, W. C., Babin, B. J., Anderson, R. E., Tatham, R. L. (2006). Multivariate data analysis. N.J.: Pearson Prentice Hall.

Hanssens, D. M., Thorps, D., \& Finkbeiner, C. (2008). Marketing When Customer Equit Matters. Harvard Business Review, 86(5), 117-123.

Hopkins, M. (2003). The business case for CSR: Where are we? International Journal of Business Performance Management, 5(2/3), 125-140. http://dx.doi.org/10.1504/IJBPM.2003.003261

Huber, F., Vollhardt, K., Matthes, I., \& Vogel, J. (2010). Brand misconduct: Consequences on consumer-brand relationships. Journal of Business Research, 63(11), 1113-1120. http://dx.doi.org/10.1016/j.jbusres.2009.10.006

Javalgi, R. G., Traylor, M. B., Gross, A. C., \& Lampman, E. (1994). Awareness of Sponsorship and Corporate Image: An Empirical Investigation. Journal of Advertising, 23, 47-58. http://dx.doi.org/10.1080/00913367.1943.10673458

Joreskog, K. G., \& Sorbom, D. (1989). LISREL 7 user's reference guide. Scientific Software International, Inc. 
Kaiser, H. F. (1958). The varimax criterion for analytic rotation in factor analysis. Psychometrika, 23, 187-200. http://dx.doi.org/10.1007/BF02289233

Kerlinger, F. N. (1978). Foundation of Behavioral Research. New York: McGraw-Hill.

Kim, Y., \& Villegas, J. (2009). Effect of Emotional Attachment to a Brand on Credibility of Information Sources. American Academy of Advertising Conference Proceedings, 73-73.

Kotler, P. (1991). Marketing Management: Analysis, Planning, Implementation and Control (7th ed.). Englewood Cliffs, NJ: Prentice-Hall.

Kotler, P. (2000). Marketing Management (The Millennium Edition). Upper Saddle River, NT: Prentice Hall International, Inc.

Kotler, P., \& Keller, K. L. (2009). Marketing management (13th ed.). Upper Saddle River, NJ: Prentice Hall.

Kwon, K. N., \& Schumann, D. W. (2010). The Influence of Consumers' Price Expectations on Value Perception and Purchase Intention. Advances in Consumer research, 28, 316-322.

Langmeyer, L., \& Matthew, D. S. (1993). Celebrity Endorsers and Public Service Agencies: A Balancing Act. In E. Thorson (Ed.), Proceedings of the 1993 Conference of the American Academy of Advertising. Columbia, MO: American Academy of Advertising.

Lee, E. M., Park, S. Y., Rapert, M. I., \& Newman, C. L. (2011). Does perceived consumer fit matter in corporate social responsibility issues? Journal of Business Research.

Lee, J. E., Jeon, J. E., \& Yoon, J. Y. (2010). Does brand experience affect consumer's emotional attachments? Korean Journal of Marketing, 12(2), 53-81.

Maignan, I., Ferrell, O. C., \& Farrell, L. (2005). A stakeholder model for implementing social responsibility in $\begin{array}{lllll}\text { marketing. } \quad \text { European Journal of } & \text { Marketing, 39(9/10), }\end{array}$ http://dx.doi.org/10.1108/03090560510610662

Marin, L., Ruiz, S., \& Rubio, A. (2009). The role of identity salience in the effects of corporate social responsibility on consumer behavior. Journal of Business Ethics, 84(1), 65-78. http://dx.doi.org/10.1007/s10551-008-9673-8

Mejri, M., \& De Wolf, D. (2012). Analysis of retailers' communication approaches in sustainability and social responsibility reports. International Journal of Marketing Studies, 4(2), 30-44.

Mohr, L. A., \& Webb, D. J. (2005). The effects of corporate social responsibility and price on consumer responses. The Journal of Consumer Affairs, 39(1), 121-147. http://dx.doi.org/10.1111/j.1745-6606.2005.00006.x

Mollen, A., \& Wilson, M. (2010). Engagement, telepresence and interactivity in online consumer experience: Reconciling scholastic and managerial perspectives. Journal of Business Research, 63(9/10), 919-925. http://dx.doi.org/10.1016/j.jbusres.2009.05.014

Morgan, R. M., \& Hunt, S. D. (1994). The commitment-trust theory of relationship marketing. Journal of Marketing, 58, 20-38. http://dx.doi.org/10.2307/1252308

Morwitz, V. G., Steckel, J. H., \& Gupta, A. (2007). When do purchase intentions predict sales? International Journal of Forecasting, 23(3), 347-364. http://dx.doi.org/10.1016/j.ijforecast.2007.05.015

Nunnally, J. C. (1978). Psychometric Theory. New York: Mcgraw-Hill.

Oliver, R. L. (1980). A cognitive model of the antecedents and consequences of satisfaction decision. Journal of marketing Research, 17(4), 460-469. http://dx.doi.org/10.2307/3150499

Park, C. W., \& Deborah J. M. (2006). What's in and what's out: questions over the boundaries of the attitude construct. Journal of Consumer Research, 33(1), 16-18. http://dx.doi.org/10.1086/504122

Park, C. W., MacInnis, D. J., Priester, J., Eisingerich, A. B., \& Iacobucci, D. (2010). BrandAttachment and Brand Attitude Strength: Conceptual and Empirical Differentiation of Two Critical Brand Equity Drivers. Journal of Marketing, 74(6), 1-17. http://dx.doi.org/10.1509/jmkg.74.6.1

Rifon, N. J., Choi, S. M., Trimble, C. S., \& Li, H. (2004). Congruence Effects in Sponsorship: The Mediating Role of Sponsor Credibility and Consumer Attributions of Sponsor Motive. Journal of Advertising, 33, 29-43. http://dx.doi.org/10.1080/00913367.2004.10639151

Roberts, J. A., \& Manolis, C. (2000). Baby Boomers and Busters: An Exploratory Investigation of Attitudes 
toward Marketing, Advertising and Consumerism. Journal of Consumer Marketing, 17(6), 481-497. http://dx.doi.org/10.1108/07363760010349911

Sexty, R. (2010). Canadian Business and Society: Ethics and Responsibilities. McGraw-Hill Ryerson Higher Education.

Shamma, H. M., \& Hassan, S. S. (2011). Integrating product and corporate brand equity into total brand equity measurement. International Journal of Marketing Studies, 3(1), 11-20. http://dx.doi.org/10.5539/ijms.v3n1p11

Sprinkle, G. B., \& Maines, L. A. (2010). The benefits and costs of corporate social responsibility. Business Horizons, 53, 445-453. http://dx.doi.org/10.1016/j.bushor.2010.05.006

Sproull, L., \& Kiesler, S. (1991). Connections: New ways of working in the networked organization. Cambridge, MA: MIT Press.

Tokman, M., Davis, L. M., \& Lemon, K. N. (2007). The WOW factor: Creating value through win-back offers to reacquire lost customers. Journal of Retailing, 83(1), 47-64. http://dx.doi.org/10.1016/j.jretai.2006.10.005

Wout, M., \& Sanfey, A. G. (2008). Friend or foe: The effect of implicit trustworthiness judgments in social decision-making. Cognition, 108(3), 796-803. http://dx.doi.org/10.1016/j.cognition.2008.07.002

Yoon, Y., Gurhan-Canli, Z., \& Schwarz, N. (2006). The Effect of Corporate Social Responsibility (CSR) Activities on Companies with Bad Reputations. Journal of Consumer Psychology, 16(4), 377-390. http://dx.doi.org/10.1207/s15327663jcp1604_9

\section{Copyrights}

Copyright for this article is retained by the author(s), with first publication rights granted to the journal.

This is an open-access article distributed under the terms and conditions of the Creative Commons Attribution license (http://creativecommons.org/licenses/by/3.0/). 